\title{
Pengaruh Penambahan Lisin dalam Ransum terhadap Berat Hidup, Karkas dan Potongan Karkas Ayam Kampung
}

\author{
Effect of Lysine Supplementation in Diet On Body Weight, Carcass, \\ and Quarter Carcass of Kampung Chicken
}

\author{
A. Yuniza, Nuraini, dan S. Hafiz
}

Fakultas Peternakan Universitas Andalas

Kampus Limau Manis Padang, 25163

(Diterima: 14 Maret 2011; Disetujui: 2 Juli 2011)

\begin{abstract}
Standard of nutrient requirements especially amino acid requirements in kampung chicken's diet was not known yet. Therefore, until now formulation of kampung chicken's diet still refferenced to nutrient requirements of laying hen. Usualy formulation of kampung chicken was based on protein and metabolizable energy requirement only, without considering about it's balances of amino acids. Amino acids that usualy deficiency in diet were lysine and methionine. Because, study about amino acid requirement of kampung chicken was limited, so this research was conducted to study effect the suplementation of lysine in kampung chicken diet on body weight, carcass, and carcass quarter of kampung chicken (thigh and breast quarter yield). The experiment was designed by using randomized completely design with 5 treatments of supplementation of lysine $(A=0 \%$ as a control, $B=0.15 \%$, $C=0.30 \%, D=0.45 \%$, and $E=0.60 \%$ ) in diet which crude protein content $14.5 \%$ and $2900 \mathrm{kkal} / \mathrm{kg}$ $M E$ with 4 replications. Parameters were: body weight, carcass weight, percentage of carcass, thigh weight, breast weight, percentage of thigh, and percentage of breast of kampung chickens. The results showed that suplementation of lysine in diet highly significant $(P<0.01)$ increased the body weight, carcas weight, thigh weight and breast weight. Suplementation of lysine in diet also significant $(P<0.05)$ increased the percentage of breast, but not significant $(P>0.05)$ on persentage of carcas and percentage of thigh. Levels supplementation of lysine bigger than $0.15 \%$ in diet $(C=0.30 \%$, $D=0.45 \%$, and $E=0.60 \%$ ) gave the same effect as at level $0.15 \%$. It concluded, the level of lysine supplementation in kampung chicken diet recomended was $0.15 \%$. Therefor it was known that requirement lysine for kampung chicken on growth periode was $0.77 \%$.
\end{abstract}

Keywords: lysine supplementation, kampung chicken, carcass, thigh, breast quarter yield

\section{PENDAHULUAN}

Ayam kampung merupakan salah satu jenis unggas lokal yang sudah lama dikenal dan dipelihara di Indonesia. Ayam kampung mempunyai peranan yang cukup besar dalam mendukung perekonomian terutama di pedesaan. Walaupun ayam broiler sudah banyak dijumpai dipasar-pasar tradisional maupun pasar modern, daging ayam kampung masih diminati oleh banyak konsumen. Hal ini karena sebagian besar masyarakat Indonesia masih merasakan bahwa daging ayam kampung lebih enak daripada daging broiler. Namun demikian, mengingat harga ayam kampung yang jauh lebih tinggi dari harga ayam broiler per kilogramnya, maka permintaan konsumen terhadap ayam kampung lebih rendah daripada ayam broiler.

Tingginya harga ayam kampung ini, salah satunya disebabkan oleh pertum buhannya yang lambat, sehingga membutuhkan ransum yang lebih banyak daripada ayam broiler, sehingga angka konversi ransum menjadi lebih besar (efisiensi ransum rendah). Untuk mendapatkan pertambahan berat badan satu kilogram saja, ayam kampung membutuhkan ransum lebih dari $2,8 \mathrm{~kg}$, sementara ayam broiler hanya $1,7 \mathrm{~kg}$. Salah satu cara meningkatkan efisiensi ransum adalah 
dengan memperhatikan keseimbangan asamasam amino yang dibutuhkan ternak.

Sampai saat ini belum diketahui standard kebutuhan gizi dan zat -zat makanan secara lengkap terutama kebutuhan asam amino bagi ayam kampung. Oleh karena itu formulasi dan susunan ransum ayam kampung sampai saat ini belum baku dan masih mengacu kepada kebutuhan ayam ras petelur. Dalam menyusun ransum ayam kampung, biasanya hanya berpatokan pada kebutuhan protein kasar dan energi termetabolis saja tanpa memperhatikan keseimbangan asam aminonya. Asam amino yang biasanya defisien dalam ransum adalah lisin dan metionin. Pada umumnya metionin sangat berperan dalam produktivitas telur, sedangkan lisin berguna dalam produksi daging. Leeson and Summers (2001) menyatakan bahwa pemberian lisin sebanyak $1,25 \%$ sampai ayam berumur 42 hari, dan sebanyak $1,06 \%$ pada periode finisher dapat meningkatkan pertumbuhan dan perkembangan dada ayam. Daging dada merupakan potongan karkas yang digemari oleh masyarakat karena dagingnya yang tebal, kandungan proteinnya yang tinggi, dan kandungan lemaknya yang rendah.

Mengingat kajian mengenai kebutuhan asam amino pada ayam kampung belum banyak, maka penelitian ini dilakukan untuk mengetahui kandungan asam amino lisin yang tepat dalam ransum ayam kampung, sehingga dapat meningkatkan berat hidup dan persentase karkasnya, serta pengaruhnya pada berat dan persentase paha dan dada ayam kampung.

\section{METODE}

Penelitian ini menggunakan DOC ayam kampung yang diperoleh dari PT. Charoen Pokphan Jaya Farm Medan sebanyak 80 ekor. Ayam dipelihara dengan ransum komersial bravo 311 (ransum ayam petelur) sampai berumur 1 minggu. Pada umur satu minggu ayam ditempatkan kedalam 20 unit kandang boks, masingmasing unit kandang terdiri dari 4 ekor ayam. Ayam dipelihara dengan ransum perlakuan selama 6 minggu. Ransum perlakuan disusun dari: jagung kuning, dedak halus, bungkil kelapa, tepung ikan, tepung tulang, minyak kelapa, top mix, dan $\mathrm{CaCO}_{3}$, dengan kandungan $14,5 \%$ protein kasar dan energi termetabolis $2900 \mathrm{kkal} / \mathrm{kg}$ (Wizna, 1992). Komposisi dan kandungan zat makanan dari masing-masing ransum perlakuan dapat dilihat pada Tabel 1 . Ransum yang disusun ini selanjutnya disebut ransum basal. Sebagai perlakuan dalam penelitian ini adalah penambahan lisin dengan beberapa level yaitu:

$$
\begin{array}{ll}
\mathrm{A} & : \text { Ransum basal (RB) } \\
\mathrm{B} & : \mathrm{RB}+0,15 \% \text { lisin } \\
\mathrm{C} & : \mathrm{RB}+0,3 \text { lisin } \\
\mathrm{D} & : \mathrm{RB}+0,45 \text { lisin } \\
\mathrm{E} & : \mathrm{RB}+0,60 \text { lisin }
\end{array}
$$

Penelitian ini menggunakan Rancangan Acak Lengkap (RAL) dengan 5 perlakuan dan 4 kali ulangan. Analisis statistik dilanjutkan dengan uji Duncan's Multiple Range Test pada hasil sidik ragam yang signifikan. Pengamatan dilakukan pada peubah berat hidup, karkas (berat karkas, dan persentase karkas), serta potongan karkas (berat paha, berat dada, persentasepaha dan persentase dada).

\section{HASIL DAN PEMBAHASAN}

Rataan berat hidup, berat karkas, dan persentase karkas ayam kampung hasil penelitian disajikan dalam Tabel 2. Hasil analisis ragam menunjukan bahwa perlakuan penambahan asam amino lisin dengan level $0 ; 0,15 ; 0,30 ; 0,45 ;$ dan $0,60 \%$ dalam ransum ayam kampung memberikan pengaruh yang sangat nyata $(P<0,01)$ terhadap berat hidup dan berat karkas, tetapi memberikan pengaruh tidak nyata $(\mathrm{P}>0,05)$ terhadap persentase karkas.

Untuk melihat perbedaan dari masingmasing perlakuan, dilakukan analisis statistik lebih lanjut dengan DMRT. Hasil uji lanjut DMRT pada peubah berat hidup dan berat karkas ayam kampung menunjukkan bahwa perlakuan A menghasilkan berat hidup dan berat karkas yang sangat nyata $(\mathrm{P}<0,01)$ lebih rendah dari pada berat 
hidup dan berat karkas dari perlakuan B, C, D, dan E. Sedangkan antar perlakuan B, C, $\mathrm{D}$, dan $\mathrm{E}$ memberikan pengaruh yang berbeda tidak nyata $(\mathrm{P}>0,05)$ terhadap berat hidup dan berat karkas. Berbeda sangat nyatanya $(\mathrm{P}<0,01)$ berat hidup dan berat karkas ayam kampung yang diberi ransum $\mathrm{A}=$ tanpa penambahan lisin (kandungan lisin ransum $A=0,62 \%$ ) dengan ransum $B, C, D$, dan $\mathrm{E}$ yang disuplementasi dengan lisin (kandungan lisin ransum $\mathrm{B}=0,77 \%, \mathrm{C}=$ $0,92 \%, \quad \mathrm{D}=1,07 \%, \quad$ dan $\quad \mathrm{E}=1,22 \%$ ) menunjukkan bahwa penambahan lisin dalam ransum ayam kampung dapat meningkatkan berat hidup dan berat karkasnya. Hasil penelitian ini menunjukkan bahwa berat hidup ayam kampung yang diberi suplementasi lisin dapat meningkat sampai $31,7 \%$ dan pada berat karkas sampai $63,1 \%$. Hal ini juga menunjukkan bahwa ransum A yang disusun dari bahan pakan konvensional dengan kandungan protein 14,5\% dan ME $2900 \mathrm{kkal} / \mathrm{kg}$ tersebut belum memenuhi kebutuhan lisin bagi ayam kampung. Oleh karena itu dengan suplementasi lisin kedalam ransum tersebut maka kebutuhan lisin ayam kampung akan terpenuhi dan ini dimanifestasikan dengan meningkatnya berat badan dan berat karkas. Anggorodi (1985) menyatakan bahwa apabila terjadi defisiensi lisin pada ternak ayam akan menyebabkan kehilangan berat badan dan pertumbuhannya akan terhambat. Oleh karena itu penambahan lisin pada ransum yang defisiensi lisin dapat meningkatkan kualitas ransum (Soeharto, 1980). Leeson and Summers (2001) menyatakan bahwa lisin lebih dibutuhkan untuk pertumbuhan dan produksi daging dari pada untuk produksi telur.

Berbeda tidak nyatanya $(\mathrm{P}>0,05)$ berat hidup dan berat karkas antar perlakuan B, C, $\mathrm{D}$, dan $\mathrm{E}$ menunjukkan bahwa penambahan lisin 0,30 sampai $0,60 \%$ memberikan pengaruh yang berbeda tidak nyata dengan penambahan lisin $0,15 \%$. Hal ini menunjukkan bahwa dengan penambahan $0,15 \%$ lisin saja sudah terpenuhi kebutuhan lisin ayam kampung, sehingga jika dosis penambahan lisin ditingkatkan sampai
0,60\% tidak menghasilkan berat hidup dan berat karkas ayam kampung yang lebih besar dari penambahan lisin 0,15\% (ransum B). Penambahan lisin 0,15\% dalam ransum ayam kampung akan meningkatkan kandungan lisin ransum menjadi $0,77 \%$. Oleh karena itu penambahan asam amino $0,30 \% ; 0,45 \%$, dan $0,60 \%$ dalam ransum menyebabkan kelebihan lisin. Kelebihan lisin ini tidak akan disintesis menjadi protein tubuh ayam kampung, sehingga tidak termanfaatkan untuk meningkatkan berat hidup dan berat karkas ayam kampung.

Dari hasil penelitian ini juga dapat diduga bahwa kebutuhan lisin ayam kampung pada periode pertumbuhan adalah $0,77 \%$. Kebutuhan lisin bagi ayam kampung ini lebih kecil dari pada kebutuhan lisin ayam ras petelur tipe ringan pada periode yang sama (periode pertumbuhan). Kebutuhan lisin pada ayam ras petelur tipe ringan pada periode pertumbuhan adalah $0,85 \%$ (NRC, 1994).

Suplementasi lisin dengan level yang tinggi sampai $0,60 \%$ dalam ransum (kandungan lisin ransum menjadi 1,224\%) ternyata belum memberikan pengaruh antagonis dengan asam amino lain terutama arginin. Hal ini terlihat dari penambahan lisin pada ransum $\mathrm{C}, \mathrm{D}$, dan $\mathrm{E}$ tersebut tidak menghambat atau menurunkan pertumbuhan. Mungkin jika dosis ditingkatkan lebih dari $0,60 \%$ akan terlihat pengaruh antagonisme lisin dengan arginin yang dapat menghambat pertumbuhan. Menurut Scoot et al. (1982) dan Anggorodi (1985) hambatan pertumbuhan ini disebabkan karena kelebihan lisin dalam ransum akan meningkatkan aktivitas arginase ginjal yang sangat mencolok, sehingga meningkatkan kebutuhan arginin.

Berbeda tidak nyatanya pengaruh perlakuan A, B, C, D, dan E terhadap persentase karkas ayam kampung disebabkan karena berat hidup dan berat karkas yang diperoleh pada masing-masing perlakuan tersebut relatif proporsional. Namun demikian, jika diperhatikan angkaangka rataan persentase karkas pada hasil penelitian ini, terlihat bahwa penambahan 
lisin dalam ransum ayam kampung menunjukkan adanya kecenderungan untuk meningkatkan persentase karkas. Hal ini terlihat dari analisis keragaman pada tingkat kesalahan $(\alpha) 10 \%$ pada peubah persentase karkas menunjukan berbeda nyata $(\mathrm{P}<0,1)$

Rataan berat paha, berat dada, dan persentase paha dan dada disajikan dalam Tabel 3. Hasil analisis ragam menunjukan bahwa perlakuan penambahan asam amino lisin dengan level $0 ; 0,15 ; 0,30 ; 0,45$; dan $0,60 \%$ dalam ransum ayam kampung memberikan pengaruh yang sangat nyata $(\mathrm{P}<0,01)$ terhadap berat paha, dan berat dada, serta pengaruh nyata $(\mathrm{P}<0,05)$ terhadap persentase dada, tetapi memberikan pengaruh yang berbeda tidak nyata $(\mathrm{P}>0,05)$ terhadap persentase paha.

Hasil uji lanjut DMRT menunjukkan bahwa perlakuan A menghasilkan berat paha, berat dada, dan persentase dada yang nyata $(\mathrm{P}<0,05)$ lebih rendah dari pada berat paha, berat dada, dan persentase dada dari perlakuan B, C, D, dan E, tetapi berbeda tidak nyata pada peubah persentase paha. Sedangkan antar perlakuan B, C, D, dan E memberikan pengaruh yang berbeda tidak nyata $(\mathrm{P}>0,05)$ terhadap berat paha, berat dada, dan persentase dada.

Lebih rendahnya $(\mathrm{P}<0,01)$ berat paha dan berat dada ayam kampung yang diberi ransum A (ransum basal, kandungan lisinnya $0,624 \%$ ) dengan ransum $\mathrm{B}, \mathrm{C}, \mathrm{D}$, dan $\mathrm{E}$ yang disuplementasi dengan lisin (kandungan lisin ransum $\mathrm{B}=0,774 \%, \mathrm{C}=$ $0,924 \%, \quad \mathrm{D}=1,074 \%$, dan $\quad \mathrm{E}=1,224 \%$ ) menunjukkan bahwa penambahan lisin dalam ransum dapat meningkatkan berat paha dan berat dada ayam kampung. Hasil penelitian ini menunjukkan bahwa berat paha ayam kampung yang diberi suplementasi lisin dapat meningkat sampai $70,3 \%$ dan pada berat dada dapat meningkat sampai $83,2 \%$. Lebih rendahnya $(\mathrm{P}<0,05)$ berat paha dan berat dada pada perlakuan A menunjukkan bahwa ransum A defisiensi lisin sehingga tidak dapat memenuhi kebutuhan lisin ayam kampung, maka sintesis protein menjadi terganggu dan mengakibatkan pertumbuhan terhambat.
Penambahan lisin dapat memperbaiki pertumbuhan termasuk otot paha dan dada sebagaimana terlihat pada hasil perlakuan B, C, D, dan E.

Berbeda nyatanya $(\mathrm{P}<0,05)$ pengaruh penambahan lisin terhadap persentase dada, namun berbeda tidak nyata $(\mathrm{P}>0,05)$ terhadap persentase paha, menunjukkan bahwa peranan lisin banyak terlihat pada perkembangan otot dada dibandingkan dengan otot paha. Hal ini sesuai dengan pernyataan Leeson and Summers (2001) dan Veldkamp et al. (2005) bahwa penambahan lisin dapat meningkatkan persentase dada. Peningkatan pada berat paha ayam kampung akibat perlakuan penambahan lisin dalam ransum terjadi secara proporsional dengan peningkatan berat hidupnya, sehingga menghasilkan persentase paha yang tidak signifikan. Sedangkan pada peubah berat dada ayam kampung, perlakuan penambahan lisin mampu meningkatkan berat dada melebihi dari peningkatan berat hidupnya sehingga dapat juga meningkatkan persentase dada ayam kampung secara signifikan.

\section{KESIMPULAN}

Hasil penelitian ini menunjukkan bahwa:

1. Penambahan lisin pada ransum yang defisiensi lisin dapat meningkatkan berat hidup, berat karkas, berat paha, berat dada, dan persentase dada ayam kampung.

2. Dosis penambahan lisin yang tepat dalam ransum basal dengan protein $14,5 \%$ dan energi termetabolis 2900 $\mathrm{kkal} / \mathrm{kg}$ adalah $0,15 \%$ yang akan meningkatkan kandungan lisin ransum menjadi $0,77 \%$.

3. Diduga kebutuhan lisin ayam kampung adalah sebesar $0,77 \%$. Angka kebutuhan ini lebih rendah dari pada kebutuhan lisin bagi ayam ras petelur tipe ringan pada periode pertumbuhan. 


\section{DAFTAR PUSTAKA}

Anggorodi, R. 1985. Kemajuan Mutakhir dalam Ilmu Makanan Ternak Unggas. PT Gramedia, Jakarta

Leeson, S., and J.D. Summers. 2001. Nutrition of The Chicken 4th Ed. University Book, Quelph, Ontorio, Canada.

NRC.1994. Nutrient Requirement of Poultry. $8^{\text {th }}$ Ed.Nat.Acad.of Sci. Washington D.C.

Scott,M.L., M.C.Nesheim and R.J. Young. 1982. Nutrition of the Chickens.3nd Ed.M.L.Scott and Associates. Ithaca : New York.
Soeharto, P.R. 1980. Protein dan Asam Amino. Majalah Poultry Indonesia. Nomor 28

Wizna, 1992. Efisiensi Penggunaan Protein Sehubungan Dengan Kebutuhan Ayam Buras Pada Periode Pertumbuhan. Tesis. Pascasarjana Universitas Andalas, Padang.

Veldkamp, T., R.P. Kwakkel, P.R. Ferket, and M.W.A. Verstegen. 2005. Growth responses to dietary energy and lysine at high and low ambient temperature in male turkeys. Poultry Sci. 84 (2): 273282.

Tabel 1. Komposisi bahan penyusun ransum penelitian dan kandungan zat makanan dan energi termetabolis ransum

\begin{tabular}{lccccc}
\hline \multirow{2}{*}{ Bahan Pakan } & \multicolumn{5}{c}{ Perlakuan } \\
\cline { 2 - 6 } & $\mathrm{A}$ & $\mathrm{B}$ & $\mathrm{C}$ & $\mathrm{D}$ & $\mathrm{E}$ \\
\hline Jagung kuning (\%) & 57,5 & 57,5 & 57,5 & 57,5 & 57,4 \\
Dedak halus(\%) & 7 & 7 & 7 & 7 & 7 \\
Bungkil Kelapa (\%) & 24 & 24 & 24 & 24 & 24 \\
Tepung Ikan (\%) & 6 & 6 & 6 & 6 & 6 \\
Tepung tulang(\%) & 1 & 1 & 1 & 1 & 1 \\
Minyak kelapa (\%) & 3,5 & 3,5 & 3,5 & 3,5 & 3,5 \\
Top mix (\%) & 0,5 & 0,35 & 0,20 & 0,15 & 0 \\
CaCO3 (\%) & 0,5 & 0,5 & 0,5 & 0,5 & 0,5 \\
Lisin (\%) & 0 & 0,15 & 0,30 & 0,45 & 0,6 \\
\hline TOTal & 100 & 100 & 100 & 100 & 100 \\
\hline Kandungan Zat Makanan dan ME & & & & \\
\hline ME (kkal/kg) & 2907,25 & 2907,25 & 2907,25 & 2907,25 & 2903,9 \\
Protein kasar (\%) & 14,48 & 14,48 & 14,48 & 14,48 & 14,48 \\
Serat Kasar (\%) & 5,65 & 5,65 & 5,65 & 5,65 & 5,65 \\
Lemak Kasar (\%) & 7,62 & 7,62 & 7,62 & 7,62 & 7,62 \\
Ca (\%) & 0,89 & 0,89 & 0,89 & 0,89 & 0,89 \\
P tersedia (\%) & 0,41 & 0,41 & 0,41 & 0,41 & 0,41 \\
Metionin (\%) & 0,30 & 0,30 & 0,30 & 0,30 & 0,30 \\
Lisin (\%) & $\mathbf{0 , 6 2}$ & $\mathbf{0 , 7 7}$ & $\mathbf{0 , 9 2}$ & $\mathbf{1 , 1 7}$ & $\mathbf{1 , 2 2}$ \\
\hline
\end{tabular}


Tabel 2. Rataan berat hidup, berat karkas, dan persentase karkas ayam kampung umur 49 hari setelah dipelihara dengan ransum perlakuan

\begin{tabular}{lccc}
\hline \multicolumn{1}{c}{ Perlakuan } & $\begin{array}{c}\text { Berat Hidup } \\
\text { (g/ekor) }\end{array}$ & $\begin{array}{c}\text { Berat Karkas }^{*} \\
\text { (g/ekor) }\end{array}$ & $\begin{array}{c}\text { Persentase karkas }^{\text {ns }} \\
(\%)\end{array}$ \\
\hline A= Ransum basal & $176,58^{\mathrm{a}}$ & $95,55^{\mathrm{a}}$ & 53,59 \\
$\mathrm{~B}=\mathrm{RB}+0,15 \%$ lisin & $218,31^{\mathrm{b}}$ & $143,93^{\mathrm{b}}$ & 66,32 \\
$\mathrm{C}=\mathrm{RB}+0,30 \%$ lisin & $232,56^{\mathrm{b}}$ & $152,28^{\mathrm{b}}$ & 65,46 \\
$\mathrm{D}=\mathrm{RB}+0,45 \%$ lisin & $225,35^{\mathrm{b}}$ & $148,20^{\mathrm{b}}$ & 65,55 \\
$\mathrm{E}=\mathrm{RB}+0,60 \%$ lisin & $232,10^{\mathrm{b}}$ & $155,83^{\mathrm{b}}$ & 67,49 \\
\hline SE & 9,85 & 9,43 & 3,62 \\
\hline
\end{tabular}

Keterangan: $*=$ hasil analisis ragam menunjukkan pengaruh sangat nyata $(\mathrm{P}<0,01)$

$\mathrm{ns}=$ hasil analisis ragam menunjukkan pengaruh tidak nyata $(\mathrm{P}>0,05)$

Superskrip yang berbeda pada nilai rataan dalam kolom yang sama menunjukkan berbeda nyata $(\mathrm{P}<0,05)$

$\mathrm{RB}=$ ransum basal

$\mathrm{SE}=$ standard error

Tabel 3. Rataan berat paha, berat dada, persentase paha dan persentase dada ayam kampung umur 49 hari setelah dipelihara dengan ransum perlakuan

\begin{tabular}{|lccc|c|}
\hline \multicolumn{1}{|c}{ Perlakuan } & $\begin{array}{c}\text { Berat Paha } \\
(\text { gram })\end{array}$ & $\begin{array}{c}\text { Berat } \\
\text { Dada }^{* * *} \\
\left(\text { gram }^{* *}\right.\end{array}$ & $\begin{array}{c}\text { Persentase } \\
\text { Paha }^{\text {ns }}(\%)\end{array}$ & $\begin{array}{c}\text { Persentase } \\
\text { Dada }^{*}(\%)\end{array}$ \\
\hline A= Ransum basal & $13,8^{\mathrm{a}}$ & $18,4^{\mathrm{a}}$ & 12,1 & $15,0^{\mathrm{a}}$ \\
$\mathrm{B}=\mathrm{RB}+0,15 \%$ & $20,9^{\mathrm{b}}$ & $27,5^{\mathrm{b}}$ & 14,6 & $19,1^{\mathrm{b}}$ \\
lisin & $23,3^{\mathrm{b}}$ & $31,4^{\mathrm{b}}$ & 15,3 & $20,7^{\mathrm{b}}$ \\
$\mathrm{C}=\mathrm{RB}+0,30 \%$ & $21,9^{\mathrm{b}}$ & $32,4^{\mathrm{b}}$ & 14,9 & $21,7^{\mathrm{b}}$ \\
lisin & $23,5^{\mathrm{b}}$ & $33,7^{\mathrm{b}}$ & 15,2 & $21,7^{\mathrm{b}}$ \\
$\mathrm{D}=\mathrm{RB}+0,45 \%$ & & & & \\
lisin & & & & \\
E= RB + 0,60\% & & & & \\
lisin & 1,28 & 2,77 & 0,55 & 1,03 \\
\hline SE & & & \\
\hline
\end{tabular}

Keterangan: $* *=$ hasil analisis ragam menunjukkan pengaruh sangat nyata $(\mathrm{P}<0,01)$

$*=$ hasil analisis ragam menunjukkan pengaruh nyata $(\mathrm{P}<0,05)$

$\mathrm{ns}=$ hasil analisis ragam menunjukkan pengaruh tidak nyata $(\mathrm{P}>0,05)$ Superskrip yang berbeda pada nilai rataan dalam kolom yang sama menunjukkan berbeda nyata $(\mathrm{P}<0,05)$

$\mathrm{RB}=$ ransum basal

$\mathrm{SE}=$ standard error 